Research Article

\title{
Epidemiology Data of Ovarian Cancer in Dr. Cipto Mangunkusumo Hospital, Jakarta
}

\section{Profil Data Epidemiologi Kanker Ovarium di RSUPN Dr. Cipto Mangunkusumo, Jakarta}

\author{
Fransisca Noela, Kartiwa H Nuryanto \\ Department of Obstetrics and Gynecology \\ Faculty of Medicine University of Indonesia/ \\ Dr. Cipto Mangunkusumo National Hospital \\ Jakarta
}

\begin{abstract}
Objective: To describe the incidence of ovarian cancer and its characteristic in Dr. Cipto Mangunkusumo Hospital in the last 5 years.

Method: This was cross sectional study design. The data was collected from Gynecology Oncology Division Cancer Registry and Dr. Cipto Mangunkusumo Hospital medical record from January 2009 to December 2013; follow up was performed to know the 4-years survival rate.

Result: There were 98 subjects in this study. The majority incidence of ovarian cancer was 45-54 years old (33.6\%); the incidence of ovarian cancer decreased with the increased number of parity; the majority histotype was epithelial (76.5\%); and most of them were diagnosed on advanced stage (55.1\%). The 4-year survival rate for epithelial type was 77\%; germinal type was $83.3 \%$; and stromal type was $100 \%$. Based on therapy, the 4 -year survival rate was $84.1 \%$ for surgical only; $83.3 \%$ in adjuvant chemotherapy group; and $68.4 \%$ in neoadjuvant chemotherapy. In the group of adjuvant chemotherapy, there was $63 \%$ patients with complete response and $41.2 \%$ patients with complete response in neoadjuvant chemotherapy.

Conclusion: The highest incidence of ovarian cancer in Dr. Cipto Mangunkusumo Hospital belongs to the age of reproductive women $(\leq 55$ years old) with the highest incidence occurs in nulliparity women. Most of the ovarian cancer cases are diagnosed in advanced stage (stage III-IV).

[Indones J Obstet Gynecol 2016; 4-2: 101-106]

Keywords: age, histotype, ovarian cancer, parity, response, stage, survival, treatment
\end{abstract}

\begin{abstract}
Abstrak
Tujuan: Mengetahui gambaran umum kanker ovarium di RSCM 5 tahun terakhir beserta faktor-faktor yang berhubungan dengan kanker ovarium.

Metode: Penelitian ini menggunakan desain potong lintang. Penelitian ini mengambil data pasien kanker ovarium di Cancer Registry divisi Ginekologi Onkologi dan rekam medis di RSCM pada periode Januari 2009 - Desember 2013, dilakukan follow up untuk mengetahui kesintasan hidup selama 4 tahun.

Hasil: Terdapat 98 subyek penelitian. Pada penelitian ini didapatkan insidensi kanker ovarium terbanyak pada usia 45-54 tahun $(33,6 \%)$, insidensi kanker ovarium menurun dengan bertambahnya jumlah anak, sebagian besar kanker ovarium merupakan tipe epitelial $(76,5 \%)$ dan sebagian besar pasien didiagnosa pada stadium lanjut (55,1\%). Kesintasan hidup 4 tahun pasien kanker ovarium tipe epitelial 77\%; tipe germinal 83,3\%; tipe stroma 100\%. Kesintasan hidup 4 tahun dengan terapi pembedahan 84,1\%; pembedahan disertai kemoterapi adjuvan 83,3\%; kemoterapi neoadjuvan sebelum pembedahan 68,4\%. Terdapat 63\% respon komplit pada kelompok kemoterapi adjuvan; dan 41,2\% pada kelompok kemoterapi neoadjuvan.

Kesimpulan: Insidensi kanker ovarium di RSCM lebih tinggi pada pasien usia reproduksi ( $\leq 55$ tahun); insidensi kanker ovarium di RSCM lebih tinggi pada pasien nulipara; dan sebagian besar pasien kanker ovarium di RSCM didiagnosis pada stadium lanjut (stadium III dan IV).

[Maj Obstet Ginekol Indones 2016; 4-2: 101-106]
\end{abstract}

Kata kunci: histologi, kanker ovarium, kesintasan, paritas, respon, stadium, terapi, usia

Correspondence: Kartiwa H Nuryanto, Department of Obstetrics and Gynecology Faculty of Medicine University of Indonesia/ Dr. Cipto Mangunkusumo Hospital, Jalan Diponegoro No. 71, Jakarta, Indonesia, 10430

Telephone: 0213100695, E-mail: kartiwa_h_nuryanto@yahoo.com

\section{INTRODUCTION}

Ovarian cancer is the second most common gynecological cancer in Western countries with a high mortality rate. In Indonesia, ovarian cancer is the third most common gynecological cancer. ${ }^{1,2}$ Unlike breast and cervical cancer, there is no effective screening method for ovarian cancer. The application of certain screening to high risk women is still controversial. 3,4
The incidence rate was varied worldwide according to geographic location, where as the rates in Asia were lower than Western countries. Highest incidence for more than 8 per 100,000 was found in developed countries. 5,6 Though Japan and Hongkong had the lowest incidence, there was an increase about $15-25 \%$ every 5 years. ${ }^{5}$ Generally, ovarian cancer had been diagnosed in older women with the incidence of 61.3 per 100,000 in 75 and 79 -year-old women. ${ }^{7}$ Moreover, the histopathology was varied according to geographic loca- 
tion. In Western countries, the rates of ovarian germ cell tumor were less than 5\%; while in Asia and Africa-American, the incidence rates achieved $15 \%{ }^{8}$

The definitive therapy for ovarian cancer is surgery with or without chemotherapy. It can be given as neo-adjuvant or adjuvant therapy. ${ }^{9}$ Several studies showed that chemotherapy as adjuvant therapy had improved overall survival rate and the recurrence of free survival. ${ }^{10}$ However, the administration of chemotherapy as neo-adjuvant was still controversial. ${ }^{8}$

We conducted this study because there were differences of ovarian cancer risk factors in every region. This study aims to evaluate the incidence of ovarian cancer in Dr. Cipto Mangunkusumo Hospital based on age, menarche and number of parity. Due to the differences of ovarian cancer mortality rate in every region, we also evaluated the survival rate based on histopathology, therapy and response rate.

\section{METHODS}

This was a cross sectional study design based on cancer registry. The inclusion data were ovarian cancer cases registered in cancer registry from $1^{\text {st }}$ January 2009 to $31^{\text {st }}$ December 2013 and had medical record. The exclusion criteria was borderline ovarian tumor. The initial step was to record the register number, medical record number, patient identity, parity, age of newly diagnosed cases, age of menarche, staging, histopathology result, cytology result, treatment regimen and response. The missing data from cancer registry were completed through medical record data. Subjects were followed-up until 30 ${ }^{\text {th }}$ November 2014.

All the data were executed using SPSS 21. The statistical data included descriptive categorical analysis for the incidence of ovarian cancer cases based on reproductive age status, menarche age, parity, cytology result, histopathology, treatment regimen and stage; while survival rate based on stage, histopathology, response rate from each treatment regimen would be analyzed using Kapplan Meier method. Survival analysis was subjects in the beginning period, subjects under censored and subjects under events from period. Ethical committee had approved the study with the register of 611/UN2.F1/ETIK/2014.

\section{RESULTS}

There were 395 ovarian cancer subjects registered in cancer registry from 2009 to 2013 . All data were tracked to hospital medical record; the incomplete data were excluded from the study. All of patients who had been diagnosed in 2009 were being excluded because of missing medical record. Moreover, most of the medical records were incomplete. There were only 98 patients fulfilled the complete data recorded in cancer registry and medical record. It consisted of 15 patients in 2010, 19 patients in 2011, 29 patients in 2012 and the rest 35 patients in 2013. The cytology documentation that was not recorded in cancer registry and medical record were tracked to Pathology Anatomy Department Dr. Cipto Mangunkusumo Hospital.

In order to evaluate the survival rate, the lost of follow-up subjects were updated based on family members' recall. However, this method was not eligible to complete the treatment response; thus it left empty response treatment. Therefore, response rate was switched to treatment response percentage.

Table 1. Demographic Characteristic of Ovarian Cancer Subjects in Dr. Cipto Mangunkusumo Hospital on the Period of 2009-2013

\begin{tabular}{lccc}
\hline \hline & $\mathbf{N}$ & $\mathbf{\%}$ & $\mathbf{9 5 \%} \mathbf{C I}$ \\
\hline Year & & & \\
$<$ 15 years & 0 & 0 & - \\
15 - 24 years & 4 & 4.1 & $0-9.2$ \\
25 - 34 years & 13 & 13.3 & $7.1-20.9$ \\
35 - 44 years & 21 & 21.4 & $13.3-30.6$ \\
45 - 54 years & 33 & 33.7 & $24.5-44.9$ \\
55 - 64 years & 19 & 19.4 & $11.8-27.6$ \\
65 - 74 years & 8 & 8.2 & $3.6-15.3$ \\
$\quad$ 74 years & 0 & 0 & - \\
Parity & & & \\
$\quad$ Nulliparity & 30 & 30.6 & $22.4-38.8$ \\
Primiparity & 19 & 19.4 & $11.3-27.7$ \\
$\quad$ Multiparity & 45 & 45.9 & $38.3-54.6$ \\
Grandemultiparity & 4 & 4.1 & $1-9.2$ \\
Menarche & & & \\
$<$ 12 years & 12 & 14.3 & $6.6-22.6$ \\
12 - 16 years & 72 & 85.7 & $77.4-93.4$ \\
\hline \hline
\end{tabular}


Table 2. Clinical Characteristic of Ovarian Cancer Subjects in Dr. Cipto Mangunkusumo Hospital on the Period of 2009 - 2013.

\begin{tabular}{lccc}
\hline \hline & $\mathbf{N}$ & $\mathbf{\%}$ & $\mathbf{9 5 \%} \mathbf{C I}$ \\
\hline Stage & & & \\
I & 32 & 32.7 & $24.8-42.8$ \\
II & 12 & 12.2 & $6.7-18.4$ \\
III & 40 & 40.8 & $29.6-50.5$ \\
IV & 14 & 14.3 & $7.1-20.4$ \\
Histotype & & & \\
$\quad$ Epithelial & 75 & 76.5 & $67.9-86.2$ \\
$\quad$ Germinal & 13 & 13.3 & $5.6-19.9$ \\
$\quad$ Stromal & 10 & 10.2 & $4.1-16.8$ \\
Cytology & & & \\
$\quad$ Positive & 29 & 38.7 & $21.3-49.4$ \\
$\quad$ Negative & 32 & 42.7 & $32.0-53.5$ \\
$\quad$ Inconclusive & 14 & 18.7 & $10.5-32.0$ \\
Therapy & & & \\
$\quad$ Surgery & 35 & 35.7 & $27.1-46.9$ \\
$\quad$ Surgery followed by adju- & & & \\
$\quad$ vant chemotherapy & 46 & 46.9 & $38.3-56.6$ \\
$\quad$ NeoAdjuvant Chemotherapy - & & & \\
$\quad$ Surgery - Adjuvant & & & \\
Chemoterapy & 17 & 17.3 & $10.2-24.5$ \\
\hline \hline
\end{tabular}

The distribution of demographic characteristic subjects were according to age, parity and age of menarche (Table 1). The distribution of clinical characteristics were according to staging of newly diagnosed cases, histopathology results, cytology results, survival rate based on histopathology, survival rate based on therapy and clinical response percentage based on therapy (Table 2).

In epithelial ovarian cancer group, the survival rate in the first year was $95.8 \%$, second year $86.8 \%$, while it was decreased on the third and fourth year becoming $77 \%$. Under observation, there were 74 patients who had completed 1-year follow up, 55 patients for 2-year follow-up, 29 patients for 3-year follow-up, while only 13 patients had completed 4-year follow-up.

In germ-cell tumor group, the first year survival rate was $91.7 \%$ and second to fifth year survival rate was $83.3 \%$. There were 12 patients completed 1-year observation, 12 patients completed for 2year, 7 patients for 3 year and 3 patients for 4-year observation. Meanwhile, 5-year survival rate of stromal type group was $100 \%$. The number of patients who completed 1, 2, 3 and 4 years of observation were $10,9,4,2$ patients, consecutively.
In surgical treatment group, first year survival rate was $97.1 \%$, second year was $90.6 \%$, third year was $84.1 \%$ and fourth year was $84.1 \%$. There were 35 patients underwent first year, 28 continued to se-cond year, 13 patients completed the third year and 4 patients had completed fourth year of observation.

First year survival rate in surgical with chemotherapy as adjuvant therapy group achieved $97.7 \%$, second year was $85.7 \%$, third and fourth year was $83.3 \%$. There were 45 patients had completed 1-year observation, then 34 patients left with 2-year survival, 19 patients completed for the 3-year and 12 patients completed through 4-year observation.

In neoadjuvant chemotherapy group, first year and second year of survival rate were 94.1\%, 79.9\%; respectively and the third and fourth year were $68.4 \%$. There were 17 patients underwent 1year observation, 14 patients continued to 2-year, 8 patients on the 3 -year, then 2 patients continued to 4-year observation.

In the group of surgery followed by adjuvant chemotherapy, the clinical response based on RECIST criteria showed $63 \%$ patients achieved complete response, $4.3 \%$ partial response, $4.3 \%$ showed progressive disease, $2.2 \%$ stable disease, while there were $26.1 \%$ patients were lost to follow up. Meanwhile, on the group chemotherapy as neoadjuvant, it showed $41.2 \%$ achieved complete response, $11.8 \%$ for partial response, $17.6 \%$ for progressive disease and $29.4 \%$ patients were lost to follow-up.

\section{DISCUSSION}

National Cancer Institute (NCI) in 2007 had reported that $47.8 \%$ of the incidence for ovarian cancer occurred in 20-60 years old. In 2015, NCI stated the incidence had been increasing for above 65 years old. ${ }^{12,13}$ John $\mathrm{K}$ Chan, et al. showed that most of ovarian cancer $(78 \%)$ had been diagnosed above 50 years old during the last 14 years. Some studies stated that the incidence of ovarian cancer in USA had increased above 64 years old. 3,6,7,11 Meanwhile, in Indonesia, the highest incidence in 2002 was diagnosed in 45-54 years old and it was decreased after that. ${ }^{2}$ This report described the incidence of ovarian cancer was varied in Indonesia.

Some studies concluded that age of menarche was a weak predictor for ovarian cancer. It also 
showed by Whitemore study where they showed the weak relationship between risk of ovarian cancer and menarche age. However, the protective effect was not found in other studies, whereas Ernestoff et al. showed the decreased odd ratio for 11-15 years old was reported not significant.7,14-17 In our study, most of the subjects $(73.5 \%)$ had their menarche on 12-16 years old, $14.4 \%$ forgot about their first menstruation and $12.2 \%$ started the menstrual period before 12 years old. The average menarche age in Indonesia was 12-16 years old.18

Whittemore reported that multiparity women had lower risk to have ovarian cancer compared to nulliparity. Based on the population, the highest protective effect was found in the first term pregnancy and increased as the number of parity. It was also stated that women with history of more than five pregnancies would decrease the risk of pregnancy to $80 \%{ }^{7,15,16}$ In our study, the most of ovarian cancer $(45.9 \%)$ was diagnosed in multiparity. The percentage of ovarian cancer would decrease along with the number of childbirth and the lowest number was found in grande multiparity subjects. The declining incidence was $36.7 \%$ between nulliparity and primiparity and $86.7 \%$ between nulliparity and grande multiparity.

Another result from this study was most of the patients were diagnosed in stage III (40.8\%). This result was different compared with previous study in 2007, whereas most of ovarian cancer cases $(56.52 \%)$ were diagnosed in early stage. ${ }^{2}$

Most of the patients (41.8\%) underwent surgical therapy; other $40.8 \%$ underwent surgery and adjuvant chemotherapy, while $17.3 \%$ received neoadjuvant chemotherapy, continued with combination of surgery and adjuvant chemotherapy. This was similar to staging distribution from newly diagnosed cases. Ovarian cancer stage $\geq$ IC will need chemotherapy as adjuvant therapy. This study also showed most of the patients were diagnosed as advanced stage; therefore, combination of surgery and chemotherapy as neo-adjuvant/or adjuvant therapy would be an alternative therapy. ${ }^{19}$

National Cancer Institute stated 4-year relative survival rate of epithelial ovarian tumor in 2007 was $51.5 \%, 59.3 \%, 66.8 \%$ and $73.6 \%$, respectively. Meanwhile, 5-year survival rate based on NCI data in 2011 was $58.7 \%$ for less than 65 years old and $28.4 \%$ for more than 65 years old. Baldwin, et al. reported the first, second and fifth year survival rate for this epithelial type was 65\%, 44\% and
$36 \%$, respectively for American women during 1995 - 2007. Furthermore, Fuh, et al. in 2015 showed Asian had higher survival rate than American women. These results added that ethnic was relative risk factor for survival rate. Several studies supported that Asian got higher survival rates compared with Western population.12,13,21,22

In this study, the result showed the survival rate for epithelial tumor in Dr. Cipto Mangunkusumo Hospital was higher than the previous studies. It was hypothesized that ethnic and majority of younger age compared to American women played role to the results. The type of ovarian cancer as well as differentiation was also contributed to survival results. The weakness of this study was majority of lost to follow up patients that might cause the accuracy of survival analysis.

Study performed by Chan, et al. stated 5-year survival rate of germ cell tumor achieved $94.7 \%$ in 2006 and NCI data had supported the similar results for $85 \%$ survival rates.3,12,13 Meanwhile, this study showed the first, second and fourth year survival rate were $91.7 \%, 83.3 \%$ and $83.3 \%$, respectively. This difference might be caused of limitation subjects (13 subjects) included to this group.

Other findings for stromal type had achieved $100 \%$ 5-year survival rate. Some studies showed 5 -year survival rate of germ cell tumor in general was more than $85 \%$. The weakness of this study was small number of subjects (10 subjects). ${ }^{4,12,19}$

On the surgery group, the results of 1-, 2-, 3-, 4year survival rates were $97.1 \%, 90.6 \% ; 84.1 \%$ and $84.1 \%$, respectively. On literature, surgery was performed to low risk ovarian cancer (stage IA-IB) with well differentiated. Surgical only had achieved $90 \%$ of curative stage and 5-year survival rate $78 \%$. The success of therapy was decided if optimal surgery results achieved. ${ }^{11,20}$ Trimbos, et al. stated that adequate surgical staging and degree of differentiation were the significant prognostic factors, instead of staging. ${ }^{20}$

The treatment response of ovarian cancer stage $\geq$ IC after adjuvant chemotherapy was determined by amount and size of tumor implant after surgical staging. ${ }^{19,23}$ Based on ACTION and ICON study, 5year survival rate after chemotherapy as adjuvant therapy was $82 \%$, and $74 \% .{ }^{19}$ In this study, survival rate of patient underwent surgery continued by adjuvant therapy was $97.7 \%$ in first year and $87.5 \%$ in the second year, also $83.3 \%$ from third 
and fourth year. However, this study did not include the operation result.

Chemotherapy as neo-adjuvant treatment is indicated to ovarian cancer with the lowest prediction to achieve optimal cyto-reduction after surgery. The other indication is ovarian cancer stage IIIC with ascites $>500 \mathrm{cc}$. One of the advantages from neo-adjuvant admission is low morbidity due to surgical procedure. Yet, the result to survival rate is unclear. Several studies showed no difference among survival rates, but the patients had better quality of life. Multicenter study in France showed survival improvement in neo-adjuvant group, while it showed no significant results in Japan. The most important prognostic factor to response of chemotherapy as neo-adjuvant therapy was if it was optimal or suboptimal-debulking. Bilici, et al. stated $50 \%$ patients would achieve 52.5 month length of life with optimal cyto-reduction. ${ }^{19,23}$

Furthermore, previous study reported 2-year survival rate in neo-adjuvant group was $90 \%$. This study showed similar results, that first year of survival rate was $94.1 \%$ and 5-year survival rate of neo-adjuvant chemotherapy was only $68.4 \%$. The reason was due to the limitation number of subjects.

Another result from combination of surgery and adjuvant chemotherapy group were $65.8 \%$ achieving complete response. Neo-adjuvant chemotherapy group showed $41.2 \%$ patients achieving complete response. Based on references, more than $50 \%$ in advanced stage patients whom received paclitaxel and carboplatin chemotherapy showed complete response, only $20-30 \%$ subjects could achieved partial response or progressive disease. $^{24}$

\section{CONCLUSION}

The highest incidence of ovarian cancer in Dr. Cipto Mangunkusumo Hospital belongs to the age of reproductive women ( $\leq 55$ years old $)$ with the highest incidence occurs in nulliparity women. Most of the ovarian cancer cases are diagnosed in advanced stage (stage III-IV).

\section{CONFLICT OF INTEREST}

No potential conflict of interest relevant to this article was reported.

\section{REFERENCES}

1. Park B, Park S, Kim TJ et al. Epidemiological characteristics of ovarian cancer in Korea. J Gynecol Oncol. 2010; 30: 21(4): 241-7.

2. Aziz MF. Gynecological cancer in Indonesia. J Gynecol Oncol. 2009; 20(1): 8-10.

3. Chan JK, Cheung MK, Husain A et al. Patterns and progress in ovarian cancer over 14 years. Obstet Gynecol. 2006; 108(3 Pt 1): 521-8.

4. Oriel KA, Hartenbach EM, Remington PL. Trends in United States ovarian cancer mortality, 1979-1995. Obstet Gynecol. 1999; 93(1): 30-3.

5. Parkin DM, Pisani P, Ferlay J. Global cancer statistics. CA Cancer J Clin. 1999; 49(1): 33-64.

6. Roett MA, Evans P. Ovarian cancer: An overview. Am Fam Physician. 2009; 15: 80(6): 609-16.

7. McLemore MR, Miaskowski C, Aouizerat BE et al. Epidemiologic and Genetic Factors Associated with Ovarian Cancer. Cancer Nurs. 2009; 32(4): 281-90.

8. Berek JS. Ovarian Cancer. In: Berek JS, editor. Novak's Gynecology. $13^{\text {th }}$ ed. Baltimore: Lippincott Williams and Wilkins; 2002: 1457-548.

9. Busmar B. Kanker Ovarium. In: Aziz MF, Andrijono, Saifuddin $\mathrm{AB}$, editors. Onkologi Ginekologi: Buku Acuan Nasional. Edisi pertama. Jakarta: Yayasan Bina Pustaka Sarwono Prawirohardjo; 2006: 468-507.

10. Winter-Roach BA, Kitchener HC, Dickinson HO. Adjuvant (post-surgery) chemotherapy for early stage epithelial ovarian cancer. Cochrane Database Syst Rev. 2009(1): CD00 4706.

11. Goodman MT, Shvetsov YB. Incidence of ovarian, peritoneal, and fallopian tube carcinomas in the United States, 1995-2004. Cancer Epidemiol Biomarkers Prev. 2009; 18(1): 132-9.

12. Kosary CL. Cancer of The Ovary. In: Ries LAG, Young JL, Keel GE, Eisner MP, Lin YD, Horner M-JD, editors. SEER Survival Monograph: Cancer Survival Among Adults: US SEER Program, 1988-2001. Patient and Tumor Characteristics: National Cancer Institute; 2007: 133-44.

13. Howlader N, Noone AM, Krapcho M, Garshell J, Miller D, Altekruse SF, Kosary CL, Yu M, Ruhl J, Tatalovich Z, Mariotto A, Lewis DR, Chen HS, Feuer EJ, Cronin KA (eds). SEER Cancer Statistics Review, 1975-2012, National Cancer Institute. Bethesda, MD, http://seer.cancer.gov/csr/1975_2012/, based on November 2014 SEER data submission, posted to the SEER web site, April 2015.

14. Ovarian Cancer: American Cancer Society; 2010 [cited 2011 May 17th 2011]. Available from: http://www.cancer.org/ acs/groups/cid/documents/webcontent/003130-pdf.pdf

15. Whittemore AS, Harris R, Itnyre J. Characteristics relating to ovarian cancer risk: collaborative analysis of 12 US casecontrol studies. II. Invasive epithelial ovarian cancers in white women. Collaborative Ovarian Cancer Group. Am J Epidemiol. 1992; 15, 136(10): 1184-203.

16. Titus-Ernstoff L, Perez K, Cramer DW, et al. Menstrual and reproductive factors in relation to ovarian cancer risk. $\mathrm{Br} \mathrm{J}$ Cancer. 2001; 2, 84(5): 714-21.

17. Banks E, Beral V, Reeves G. The epidemiology of epithelial ovarian cancer: a review. Int J Gynecol Cancer. 1997(7): 425-38. 
18. Batubara JR, Soesanti F, van de Waal HD. Age at menarche in Indonesian girls: a national survey. Acta Med Indones. 2010; 42(2): 78-81

19. Andrijono. Sinopsis Kanker Ginekologi. Jakarta: Divisi Onkologi Departemen Obstetri dan Ginekologi FKUI RSCM; 2004: 211.

20. Trimbos JB, Vergote I, Bolis G et al. Impact of adjuvant chemotherapy and surgical staging in early-stage ovarian carcinoma: European Organisation for Research and Treatment of Cancer-Adjuvant Chemo Therapy in Ovarian Neoplasm trial. J Natl Cancer Inst. 2003; 15, 95(2): 113-25.

21. Fuh KC, Shin JY, Kapp DS et al. Survival Differences of Asian and Caucasian Epithelial Ovarian Cancer Patients in the United States. Gynecol Oncol. 2015; 136(3): 491-8.
22. Baldwin LA, Huang B, Miller RW et al. Ten-Year Relative Survival for Epithelial Ovarian Cancer. Obstet Gynecol. 2012; 120(3): 612-8.

23. Bilici A, Salepci T, Dane F et al. Neoadjuvant chemotherapy followed by interval cytoreductive surgery in patients with unresectable, advanced stage epithelial ovarian cancer: a single centre experience. Arch Gynecol Obstet. 2010; 282(4): 417-25.

24. Eisenhauer EA, Therasse P, Bogaerts J et al. New response evaluation criteria in solid tumours: revised RECIST guideline (version 1.1). Eur J Cancer. 2009; 45(2): 228-47. 